\title{
Óvodások múzeumi tanulása - Kirándulni volna jó! Játék és tanulás a múzeumok világában
}

\author{
Pál Fanni \\ Budaörsi Csicsergő Óvoda, Budaörs
}

\begin{abstract}
Absztrakt
Egy múzeum, múzeumpedagógia-foglalkozás „kinyitja a világot” a gyermek előtt: új tapasztalatokat szerezhet, kérdéseket tehet fel, és válaszokat kaphat, de nem utolsó sorban követhető viselkedéskultúrát sajátíthat el. Tanulmányom az óvodások múzeumi tanulását mutatja be a Magyar Természettudományi Múzeum, és a Hetedhét Játékmúzeum óvodáskorú gyerekeknek szóló múzeumpedagógiai programjain keresztül. Az óvodások minél sokszínủbb múzeumi tanulásának lehetőségeit vizsgálva a kutatás célja a Magyar Természettudományi Múzeumban, és a Hetedhét Játékmúzeumban folyó múzeumpedagógiai munka megismerése empirikus kutatással. A kutatás fókuszában a múzeumok által szervezett múzeumpedagógiai programok, kiállítások lehetőségeinek feltárása áll, illetve annak vizsgálata, milyen tényezők szükségesek az óvodás gyermekek múzeumi tanulásának biztosításához. Különösképpen arra igyekszem rávilágítani, hogy a múzeumpedagógia, illetve a múzeumlátogatás fontos és meghatározó egy óvodáskorú gyermek fejlődésében és tanulásában. A felvetett kérdésekre múzeumpedagógiai foglalkozások megfigyelésével, illetve a kutatásban önkéntesen részt vevő múzeumpedagógusok, muzeológusok, és óvodapedagógusok véleményei, tapasztalatai, nézőpontjai által kívánok válaszokat kapni.
\end{abstract}

Kulcsszavak: játék, tanulás, Hetedhét Játékmúzeum, Magyar Természettudományi Múzeum, gyermekkultúra

\section{A 21. századi gyermekkép}

Az elmúlt évszázadok során minden kornak megvolt a gyermekség mibenlétének értelmezése, amelyet az ókortól napjainkig a neveléstörténet és a pszichológia egyaránt elődeként tart számon. A gyermekekről alkotott pedagógiai kép, felfogás, vélekedés az idők folyamán folyamatosan változott és a mai napig alakul, formálódik (Vajda, 2005; Hollósi, 2008).

Az ókori társadalmakban fontos szerepet tulajdonítottak a gyermeknek, felismerték a nevelés szükségességét, így már egészen kis korban elkezdték a gyermek formálását. A humanista gyermekszemléletben már megjelenik a nevelés 
kérdései iránti érzékenység és a gyermekkor iránti érdeklődés. A felvilágosodás korában a nevelhetőség kérdése tovább erősödik. A 19. század végén megindul a gyermeket leíró jellegű tanulmányozás, megfogalmazódik egy új, antropológiailag is megalapozott gyermekkép. Új filozófiai és pszichológiai irányzatok bontakoznak ki, - mint például a pozitivizmus, pragmatizmus, amelyek elősegítették a gyermekkép formálódását (Pukánszky, 2004). Megjelenik a gyermekkel kapcsolatos tudományos megfigyelés igénye, terjed a gyermektanulmányi szemléletmód. A pszichoanalízis térnyerése felerősítette a gyermekközpontúságot, így az intuitív és tudattalan tanulás is figyelmet kapott. A gyermektanulmány (pedológia) világszerte nagy befolyással volt a gyerekvilágot közvetlenül érintő szférákra, az óvodák, iskolák világára, a gyermekekkel összefüggő iparcikkek modernizációjára, és a „gyermekkultúra” mint jelenség kialakulására (Bús, 2013).

A 20. század utolsó harmadától a narratívák a gyermekkor haláláról beszélnek. Az 1980-as években Neil Postman (1983) a gyermekkor eltünéséről beszélt híres írásában. Postman a gyermekkor eltűnését leginkább a modern tömegkommunikáció, a televízió elterjedésével hozta összefüggésbe, hiszen a képi információ befogadásához nem volt szükség speciális tudásra, így a gyermeket sokkal nehezebben lehetett kizárni ebből a tevékenységből, így a felnőtt már nem tudta ellenőrzése alatt tartani őt (Postman, 1983).

A globalizálódó világban a képi kultúra elterjedésével a gyermek-felnőtt viszony évszázados modellje átalakulóban van. A posztmodern korban a gyermekség számos formája létezik, amelyek egymás mellett élnek. A gyermekség mibenlétének értelmezése napjainkban számos tudományterületen elengedhetetlenné vált. A gyermekkor értelmezésére irányuló tudományos munka a pszichológia, pedagógia és a szociológia tudományterületein olyan elméleti és gyakorlati tudást biztosít, amely segíti az intézményes nevelést, a pedagógusokat, a szülőket, általában a gyermekekkel foglalkozó szakembereket, hogy egy komplexebb, differenciáltabb „gyermekkép” jelenjen meg tudatukban és a neveléstudomány kutatásai között (Golnhofer \& Szabolcs, 2005).

A gyermekkor új szabályai konstruálódnak nap mint nap. Az elsődleges és másodlagos szocializációs közegek már kevésbé tudnak hatást gyakorolni a gyermekekre és az új, negyedleges szocializációs közeg, a média és a tömegkommunikáció befolyásolja a gyermekkort (Nagy \& Trencsényi, 2012). A millenniumi generáció gyermekei a felgyorsult világ információdömpingjében egyensúlyoznak, miközben úgy érezhetik, hogy „magukra hagyottan bolyonganak" (Tari, 2011, p. 29).

\section{Az óvodás gyermek életkori sajátosságai}

Egy 3-6 éves korú gyermek más módon ismerkedik a világgal, mint egy iskoláskorú gyermek vagy egy felnőtt. Azonban ő is emlékezik, gondolkodik, beszél, játszik, vagy rajzol akárcsak egy felnőtt, ugyanakkor a megismerési folyamataiból hiányoznak azok a rendezőelvek, tapasztalati támpontok, amelyek nélkül a felnőttek a tevékenységeiket el sem tudják képzelni. Ezért is 
szokták a felnőttek az óvodáskorú gyermek világát varázslatos világnak emlegetni, hiszen ebben a világban a „csoda” bármikor megtörténhet. A „csodák" a valóságot helyettesítik, amely a gyermek értelmének fejlődésével lassan tovaszáll. Egy óvodás a vágyait nem választja el a valóságtól, képzeteinek áramlását vágyai vezérlik: „csiribú-csiribá” csak egy varázsszó, és a tárgyak beszélnek, a gonosz boszorkány csúf békává változik (Ranschburg, 2002).

A gyermek ebben a korban még nem képes értelmezni a körülötte lévő világot, helyette saját világot teremt magának, melyben a csodák valóságként szerepelnek. A valóság és a csodák világa közötti hasadékokat fantáziájával tölti ki, amelyet csodateremtő módszerek segítségével kelt életre. Ilyen csodateremtő módszer a játék, rajz, mese, melyek pótlásul és megoldásul szolgálnak, hogy a gyermek megértse a felnőttek világát. A csodateremtő módszerek lényeges eleme a fantázia, az illúzió, melyek révén a gyermek képzeletében kalandokat élhet át, óriássá vagy királylányt mentő királyfivá válhat (Krisztián, 2011).

\section{Az óvodáskori gondolkodás jellemzői}

Egy újszülött fejében a külső világ sem képi, sem fogalmi formában nem jelenik meg, "gondolkodása” azokban a vele született reflexes cselekvésekben nyilvánul meg, amelyekkel a külvilág ingereire reagál. Ezek a reflexek a tapasztalatok hatására folyamatosan változnak. Óvodáskorban a gyermek a megismerésnek, a gondolkodásnak egy új szakaszába lép (Ranschburg, 2002).

Piaget vizsgálataiból megállapította, hogy a gyermeki gondolkodást 7-8 éves korig a játék tölti ki, ezért eddig az életkorig nagyon nehéz elkülöníteni a játékot és a gondolkodást. Egy óvodás minden cselekvése, megnyilvánulása érzelmein keresztül közelíthető meg, érzelmein keresztül befolyásolható (Gerő, 2003). Jean Piaget által kidolgozott értelmi fejlődés szakaszosságának elmélete alapján óvodáskorra a müvelet előtti szakasz (2-7 év) tehető. A müvelet előtti gondolkodás Piaget szerint egy kiegyensúlyozatlan állapot, ugyanis a korábban kialakult cselekvési sémák zavarják az új helyezthez való alkalmazkodást. „Óvodás gyerek előtt agyaggolyót gyúrunk. A golyót azután a szeme láttára átgyúrjuk hosszú, vékony rúddá. A gyerek hol azt mondja, hogy a golyóban van több anyag, mert vastag, hol meg, hogy a rúdban van több, mert hosszú" (Mérei \& V. Binét, 2016, p. 311). Óvodáskorban az egy szempontú szemlélet időszaka a jellemző. A gyermek egy műveletben emlékszik a múltra, elképzeli a jelent és látja a jövőt (Gerő, 2003; Mérei \& V. Binét, 2016).

Ebben a korban a gyermeki szemléletre a szinkretizmus jellemző, amikor még a gyermek tagolatlan, globális jelleggel szemléli az őt körülvevő világot, és még nem képes a részleteket felismerni. A szinkretikus sémák lehetővé teszik a fantázia müködését, amelyben az emlékek az eredeti élmény alapján, de a sürítés révén eltorzítva idéződnek fel (Mérei \& V. Binét, 2016).

Jean Piaget az egocentrizmust a gyermek általános tulajdonságának tekintette. Az egocentrizmus a gondolkodás azon sajátosságára utal, hogy a gyer- 
mek a világot csak a saját nézőpontjából szemléli, a helyzetek megítésélésében a gyermek igen szubjektív. A gyermek a valóságról nyert elképzelésének egyetlen centruma van: a saját énje (Fraiberg, 2005).

Egy óvodáskorú gyermeknek kialakult világképe van, amelynek legfőbb jellemzője a mágikus gondolkodás (világa tele van csodákkal, minden megtörténehet). A tapasztalat és ismeret szintkülönbsége miatt a megértés és magyarázat igénye olyan dolgokra is kiterjed, melyekről nincsen közvetlen tapasztalata a gyermeknek (Mérei \& V. Binét, 1970).

\section{A játék és tanulás értelmezése óvodáskorban}

Önfeledt boldogság, öröm, kíváncsiság, kreativitás, elmélyültség, aktivitás, kettős tudat - csak néhány példa, amely egy játszó gyermeket jellemez. A játék a gyermek számára egy elvarázsolt világot jelent, ahol önmaga lehet (Körmöci, 2002).

A játék magyarázatára számtalan elmélet született. A játék csecsemőkorban az érzékszervi-mozgásos periódusban kezdődik, és az ember egész életében jelen van valamilyen tevékenység formájában. A gyermek játéka a humánum egyik jellemzője (Millar, 1968). „A játék a kisgyermekkor legfontosabb és legfejlesztőbb tevékenysége, s így az óvodai nevelés leghatékonyabb eszköze."1 A játék jellemzőit vizsgálva elmondhatjuk, hogy a játék a gyermek olyan tevékenysége, amelyet szabadon választ, és amely minden külső kényszertől mentes. A gyermek elemi pszichés szükséglete hogy egész nap játszhasson. Egy játék akkor szabad, ha nincs tanító jellege, hanem a gyermek a saját fantáziájának megfelelően játszhat (Körmöci, 2002).

A tanulás különböző elméletei pszichológiai választ adnak arra, hogy egy tanulási folyamat miképpen megy végbe, milyen folyamatok és irányítások szükségesek hozzá (Atkinson \& Hilgard, 2005). A tanulást, a tanulás folyamatát leíró különféle megközelítés és irányzat közös vonása szerint a tanulás az egyén viselkedésében és személyiségében bekövetkezett tartós változás, amely magában foglalja az új ismeretek és készségek elsajátítását, valamint a meglévő képességek további fejlődését. Ez a meghatározás az óvodáskorú gyermekekre akkor alkalmazható igazán, ha a tanulás minden mozzanata játéktevékenység, játékos jellegű (Kovácsné, 2009).

\section{Óvodai tevékenységekben megvalósuló tanulás}

Az óvodai tanulásról való vélekedés megosztja a felnőtt világot mind hazai, mind nemzetközi szinten. Vannak olyan felfogások, akik szerint óvodáskorban minden megtanítható a gyermeknek, és minél korábban kell megkezdeni a kisgyermek tanítását. Ezzel szemben pedig vannak akik úgy gondolják, hogy a gyermeket nem szabad tanítani, semmiféle tudatos és tervszerủ fo-

${ }^{1}$ 363/2012. (XII. 17.) Kormányrendelet az Óvodai nevelés országos alapprogramjáról. I. melléklet, $\mathrm{V} / 1$. 
lyamatba bevonni, és hagyni kell spontán a korának megfelelően fejlődni. Az eltérő nézetek, vélekedések oka egyrészt a nevelésről és a gyermekekről való felfogásban kereshető, másrészt a kultúra, és a személyes élmények hatása. A mai felfogás szerint azonban a játék és tanulás is lehet spontán, önszabályozott, egyéni és társas örömszerző tevékenység (OECD, 2006).

Magyarországon az óvodáskorú gyermekekre vonatkozóan az Óvodai nevelés országos alapprogramjában (a továbbiakban: Alapprogram) a jelenleg érvényes változatában a tevékenységekben megvalósuló tanulás az alábbiak szerint fogalmazódik meg: "Az óvodában a tanulás folyamatos, jelentős részben utánzásos, spontán és szervezett tevékenység, amely a teljes személyiség fejlődését, fejlesztését támogatja. (...) Az óvodapedagógus a tanulás irányítása során, személyre szabott, pozitív értékeléssel segíti a gyermek személyiségének kibontakozását." ${ }^{2} \mathrm{~A}$ tanulás az Alapprogram szerint tehát a tanulás és a játék, a játékosság nem egymást kizáró, hanem feltételező fogalmak. Az óvodapedagógus célja olyan tanulási tevékenységet, motivált állapotot létrehozni, amelyben a külső késztetések a gyermek belső késztetéseivel találkoznak. Ezzel a belső késztetéssel (kíváncsisággal) a gyermek szabadon eldöntheti, szívesen választhatja a tanulási tevékenységet. Egy gyermek akkor válik érdekeltté a tanulási folyamatban, ha a tanulás beindulása meghagyja a gyermek számára a szabad választás érzését (Körmöci, 2002).

\section{Múzeum kora gyermekkorban}

A 21. századi modern múzeum feladata a gyűjtő- és tudományos munka mellett, az ismeretátadás, a kultúra megőrzése és továbbadása, és az egész életen át tartó tanulás támogatása. A műgyűjtés, a tárgyak gyűjtése, megőrzése az ókortól jelen van az emberek életében. A felvilágosodás gondolkodóinak köszönhetjük a kincstárakban, fegyvertárakban, könyvtárakban őrzött kulturális örökség nyilvánossá tételét (Arapovics, 2017).

Az 1946-ban alapított Múzeumok Nemzetközi Tanácsa (International Council of Museums, ICOM) a múzeumok közönségkapcsolati, közművelödési tevékenységének fontosságát hangsúlyozza, feladatai között a szakmai együttmüködés és eszmecsere, szakemberképzés, szakmai színvonal emelése és etika kidolgozása, propagálása, valamint az örökség megőrzése szerepel (Koltai, 2011). Az ICOM meghatározásában a múzeum fontos tanulási helyszín, mivel nem csupán gyüjt, kutat, konzervál, hanem kiállít, közzétesz, oktat, nevel és szórakoztat is ${ }^{3}$.

${ }^{2} 363 / 2012$. (XII. 17.) Kormány rendelet az Óvodai nevelés országos alapprogramjáról. I. melléklet, V/5.

${ }^{3}$ Az ICOM múzeum definícióját a következőképpen határozza meg: „A múzeum nem profitra törekvő, a társadalom és fejlődése szolgálatában álló, a köz számára nyitott, állandó intézmény, amely az emberek és környezetük tárgyi emlékeit gyüjti, megőrzi, kutatja, feltárja és kiállítja tudományos, közművelődési és szórakoztató céllal.” (ICOM szakmai etikai kódex. 1986, Alapszabály 2. cikkely 1. pont.) 
Magyarországon a muzeális intézményekről, a nyilvános könyvtári ellátásról és a közművelődésről szóló 1997. évi CXL. törvény megfogalmazása szerint „a múzeum a kulturális javak tudományosan rendszerezett gyüjteményeiből álló muzeális intézmény, amely a kulturális javakat és a szellemi kulturális örökség elemeit tudományos, örökségvédelmi, oktatási és ismeretátadási céllal gyűjti, megőrzi, feldolgozza, kutatja és kiállítja, továbbá egyéb formákban közzé teszi. Tevékenységével elősegíti a természeti, társadalmi, művészeti, kulturális és tudományos összefüggések kutatását, megértését, nyomon követi azok jelenkori változásait és folytonos művelődésre ösztönöz."

\section{Múzeum helye az óvodai nevelésben}

A 21. században a múzeumok megszokott feladatai között egyre hangsúlyosabb szerepet kap az oktató-nevelő funkció, amely lehetővé teszi az óvodák, iskolák és múzeumok közötti szoros együttmüködés kialakítását is. A múzeumok működésére vonatkozó jogszabályok alapján a múzeumok többsége önmagát nyitott és befogadó intézményként határozza meg, illetve támogatja a jogszabályi meghatározásban is szereplő oktatási-ismeretátadási szerepkört, mely mögött - egyebek mellett - a múzeumpedagógiai tevékenység áll (Beáné Losonci, 2019).

Több tanulmány is tárgyalja a múzeumban folyó tanulás lehetőségeit (Vásárhelyi \& Kárpáti, 2011; Kolosai, 2017; Torgyik, 2018), amihez jól használható, gyakorlatias anyagok állnak rendelkezésére az ezen a területen tevékenykedő pedagógiai munkát végző szakemberek számára (Foghtűy \& Harangi, 1993; Foghtűy \& Szepesházyné Kurimay, 2009). Az eddigi kutatások is alátámasztják, hogy a múzeumnak van helye a köznevelésben, és az oktatásinevelési folyamatban fontos szerepet játszik a múzeumi tanulás (Beáné Losonci, 2019; Halászné Szakács, 2017; Takács \& Csimáné Pozsegovics, 2016a). A múzeumok célként fogalmazzák meg, hogy a köznevelés intézményei természetes módon építsenek a múzeumpedagógiai kínálatra, és azt tudatosan építsék be pedagógiai programjukba, oktatói-nevelői munkájukba, és hasznosítsák ezeket a lehetőségeket (Koltai, 2010).

A múzeumpedagógiai foglalkozások kisgyermekkorra vonatkozó módszertani útmutatók száma kevés, ez vitathatatlan tény. Az óvodáskorú gyermekek múzeumi foglalkoztatása szempontjából kiemelt jelentőségű a múzeumpedagógia módszertanának pontos kidolgozása (Kolosai, 2017). Ehhez szükséges az életkor-specifikus kérdések, pedagógiai és didaktikai módszerek szélesebb körű feltárása, illetve a múzeumpedagógiai tevékenység teljes folyamatát biztosító elemek kidolgozása (Beáné Losonci, 2019).

${ }^{4}$ 1997. évi CXL. törvény 


\section{Külsö helyszínen megvalósuló óvodai foglalkozás: egy múzeumlátogatás}

Az óvoda intézményét és óvodai nevelést szabályozó Alapprogram (2012) az óvoda kapcsolatait nyitott és kezdeményező intézményként határozza meg, amely lehetővé teszi a múzeumokkal való kölcsönös kapcsolatok kialakítását.

Az Alapprogramban (2012) megfogalmazott tevékenységi formáknak, illetve az óvoda helyi programjának megfelelően az óvodapedagógus tudatosan építheti bele pedagógiai tevékenységrendszerébe a múzeumlátogatást, múzeumpedagógiai foglalkozást, hogy elősegítse a gyermek sokoldalú és harmonikus fejlődését. Az óvodai környezet mellett a múzeumi környezet a nevelés egyik lehetséges külső helyszínét biztosítja, amely formálja a gyermek viselkedéskulturáját (Bihariné, 2006).

Óvodában a külső helyszínen megvalósuló óvodai nevelés a külső világ tevékeny megismerése során legtöbbször kirándulásokkal valósulhat meg. A kirándulások rendkívül sokféle formát ölthetnek, ide tartozik az is, amikor az óvodapedagógus a gyerekekkel elmegy megnézni egy múzeumot, és igyekeznek valamilyen témában minél több tapasztalatot szerezni. Ilyenkor a külső helyszínen rendkívül határozott céllal vizsgálódnak a gyerekek. A kirándulások során rendkívül nagy jelentősége van a felkészülésnek. Az előkészítés nem csak a technikai feladatokat jelenti, hanem a tartalmi előkészítést is. Nem elég, ha hagyjuk, hogy a gyermek magától fedezze fel az észrevehető jelenségeket, összefüggéseket, kapcsolatokat, törvényszerűségeket. A gyerek akkor fog bármit is észrevenni és felfedezni, ha tudja, hogy mit kellene észrevennie, látnia. Tehát egy múzeumi látogatás előkészitése a legfontosabb feladat: az a tudatos felkészülés, amely valóban biztosítja a gyerekek számára, hogy észrevegyenek valamit (Ádám et al., 2007).

A múzeum tárgyi környezete lehetőséget nyújt, hogy a gyermek minél többet tapasztalhasson közvetlen környezetéből. Egy múzeumlátogatás, múzeumpedagógiai foglalkozás elősegíti a gyermek múzeum iránti szeretetét személyes és élményalapú tapasztalat segítségével, így felnőtt korára múzeumot értő és szerető felnőtté válhat. Továbbá az óvodáskori múzeumlátogatás segíthet abban, hogy a felnövekvő nemzedék érzékennyé váljon a múzeumok látogatására és ápolására (Bihariné, 2006).

\section{Múzeumpedagógia: játék és tanulás}

\section{Múzeumpedagógia}

„A múzeumpedagógia elmélete a felvilágosodás eszmevilágában és a 20. század elején megjelenő reformpedagógiai irányzatokban gyökerezik. A felvilágosodás korában jelent meg az a törekvés, hogy a gyüjtemények által őrzött kulturális örökséget közkinccsé kell tenni." (Koltai, 2011, p. 48). 
A komplex múzeumi tanulás magába foglalja az interaktivitást, a tárgyakon és cselekvésen keresztüli tanulást, amely a múzeumi tanulás legfontosabb mozzanatai. Jean Piaget mellett a múzeumpedagógia elméletének fejlődésére John Dewey is nagy hatással volt. Elméletében a gyermeket aktív, információkereső lényként határozza meg, ami a mai múzeumpedagógiai gyakorlat alapjának tekinthető (Koltai, 2011).

A múzeumpedagógia fogalmának meghatározása nehéz feladat, ugyanis gazdag terminológiája miatt számos megnevezést használnak, mint például múzeumi kreatív foglalkozás, múzeumi népmủvelés vagy a múzeumandragógia. A múzeumi foglalkozások alapja a múzeumi gyűjtemény és az abból létrehozott állandó vagy időszaki kiállítások. A múzeumpedagógia oktatásinevelési célja a múzeumi gyüjteményhez kapcsolódó ismeretanyag átadása pedagógiai eszközök segítségével, és ezzel felelősségteljes, a múlt emlékeit és a természetet tisztelő, óvó, és azok érdekében cselekvőképes felnőttek nevelése (Koltai, 2011).

A múzeumpedagógiai foglalkozás nem pótolhatja az óvodában folyó nevelést, de egy izgalmas múzeumlátogatás során a hagyományos környezetből kilépve a gyermek más kontextusban szerezhet élményeket, tapasztalatokat; játszva, szórakozva (edutainment azaz szórakozva tanulás) mélyítheti el a már meglévő ismereteit, illetve szerezhet új tapasztalatokat (Nagy, 2014).

Óvodáskorban a játék, megfigyelés és kérdezés a tudás megszerzését segíti elő. Egy egészséges óvodás állandóan kérdez, megfigyel, amihez elég időt kell neki biztosítani, hogy fantáziája müködhessen. Egy óvodáskorú gyermek nem tud sokáig figyelni a tanításra, de ami a figyelmét önkéntelenül felkelti, elég motiváció az érdeklődés fenntartására (Kolosai, 2017). A sokszínű múzeumpedagógiai módszerek, tevékenységi formák lehetőséget kínálnak a múzeumi aktív tanulás megteremtésére, amelyet érdeklődést felkeltő eszközökkel, kézbe vehető tárgyakkal, jól irányatott kérdésekkel valósítanak meg (Koltai, 2011).

\section{Játék és tanulás a múzeumpedagógiai foglalkozásban}

A gyermek cselekvésének, tevékenységének fontossága a reformpedagógiai elképzelések keretében fogalmazódik meg először. A reformpedagógiai gondolkodók számára a gyermek egy aktív, cselekvő lény, akinek tevékenysége szabad (Nahalka, 2002).

A pedagógus feladata nem a tanulnivalók kijelölése és átadása, hanem az önálló elsajátítás feltételeinek megteremtése (Nahalka, 2002). A múzeumban megvalósuló múzeumpedagógiai foglalkozás közben a gyermek nem csak tapasztal, játszik, de tanul is. A tanulás társas környezetben, a múzeumpedagógus felnőtt irányításával, tanítói környezetben valósul meg (Takács, 2013).

A múzeumi tanulás meghatározására számtalan definíció született. Barry Lord amerikai tudós, a múzeumi tanulás fogalmának egyik első leírója, az alábbiak szerint határozza meg a múzeumi tanulást: „A múzeumi tanulás egy olyan informális, önkéntes környezetben szerzett transzformatív, affek- 
tív tapasztalat, melyben új attitüdöket, érdeklődéseket, értékeléseket, megygyőződéseket vagy értékeket fejlesztünk ki” (Lord, 2007, p. 17).

A múzeumok speciális közegében az óvodai nevelés nem megszokott környezetben, nem megszokott módon és segítőkkel folyik, ennek ellenére, az itt elsajátított tartalmak sokkal inkább beépülnek a már megszerzett ismeretek közé, könnyebben előhívhatóak, sokkal inkább eredményezi az új tapasztalatszerzést (Takács \& Csimáné Pozsegovics, 2016a). Az óvodáskorú gyerekek részére összeállított múzeumpedagógiai foglalkozás nevelési céllal tudatosan tervezett és megvalósított játékok sorozata. A múzeumpedagógia során megvalósuló játékokban a foglalkozásvezető az irányító, ő kínálja fel a játéklehetőséget a gyerekeknek. A gyermek a játékot a társaival együtt közösen éli át tapasztalás és szórakozva tanulás formájában. A felkínált játéklehetőségekben a játék kedvéért, a kíváncsisága kielégítése érdekében vesz részt. A belső motivációt a játékban való részvétel és a játéktudat biztosítja, illetve a tevékenységet támogató külső környezet, múzeumpedagógiai eszközök megteremtik számára a kedvező feltételeket a játék kibontakozásához. A gyermek a játékéban a kíváncsiság által hajtva észrevétlenül tapasztal és tanul. Játék közben megvalósuló aktív és interkatív cselekvés, a kézbe vehető tárgyakkal való ismerkedés lehetővé teszi a tapasztalást és tanulást (Elekes, 2012).

Az óvodáskori múzeumi tanulás elősegíti a komplex látásmód kialakítását, fejlesztését, öszzefüggésekre mutat rá, elmélyíti, kiegészíti, gyakoroltatja az óvodában szerzett tapasztalatokat. A múzeumi gyüjtemények szemléltetnek, felkeltik az érdeklődést adott témával kapcsolatban, továbbgondolkodásra ösztönöznek, fejlesztik a különböző képességeket, készségeket. Ezért egy múzeumi gyűjtemény, kiállítás, múzeumpedagógiai foglalkozás oktatásinevelési célú érvényesítése már óvodás korban fontos és meghatározó a gyermek fejlődésében és tanulásában (Takács \& Csimáné Pozsegovics, 2016b).

A múzeumi tanulás tehát jóval több, mint puszta tudományos ismeretátadás, hiszen részét képezi a kultúrának, a gyermekkultúrának. Az értékek, értékrendszerek kialakítása, valamint azok belsővé tétele egy egész életen át tartó tanulás folyamata, így a gyermek számára elérhetővé kell tenni a kultúrát és a tudományt, és elő kell segíteni azok megértését (Koltai, 2011; Kolosai, 2016).

\section{Óvodások a Magyar Természettudományi Múzeumban - Természet és tudomány játélkos környezetben}

Budapest egyik család- és óvodásbarát múzeuma a Magyar Természettudományi Múzeum a harmadik legidősebb múzeum Európában, amely nemcsak a természet és a tudomány iránt érdeklődő nagyoknak, hanem az óvodáskorú gyerekeknek is egyedülálló élményt nyújt a látványos kiállításaival, múzeumpedagógiai foglalkozásaival ${ }^{5}$.

${ }^{5}$ Magyar Természettudományi Múzeum Küldetésnyilatkozata. http://www.nhmus.hu/hu/ rolunk/kuldetes 
A múzeum kiállításai rendhagyó, interaktív módon mutatják be a Kárpátmedence és a világ természeti érdekességeit, szépségeit. A kiállítások között megtalálható a jelenlegi és a letűnt állat- és növényvilág, amely 2011-ben az Év Múzeuma címet is elnyerte. Emellett megismerhetjük a megkövült állatmaradványokat, dinoszauruszokat, ősembereket, és napjaink élővilágát. Mindemellett betekintést nyerhetünk a magyar fauna állatvilágába; Ázsia, Afrika élővilágán keresztül pedig a trópusi tengerek korallzátonyának lakóit vehetjük szemügyre ${ }^{6}$. Ez a múzeum a „tanulás, a kikapcsolódás, szemlélődés, elmélyülés, a rácsodálkozás lehetőségét" kínálja a látogatóknak (Vásárhelyi, 2010, p. 20).

\section{Múzeumpedagógiai foglalkozások óvodásoknak}

A múzeum kiállításaiban bemutatott tárgyak, jelenségek, tudományterületek alaposabb megismerését, feldolgozását célzó múzeumpedagógiai programokat igyekszik úgy kialakítani, hogy minden látogatói réteg megtalálja az őt érintő témát. A sokszínű múzeumi órák óvodás kortól a középiskolás korosztályig elérhetőek. A különböző korosztályok igényei alapján összeállított múzeumpedagógiai foglalkozásokon számos eredeti tárgy és hiteles másolat várja a természet csodáinak felfedezőit. A múzeum óvodásoknak ajánlott múzeumpedagógiai foglalkozásai az 1. táblázatban olvashatóak.

\section{1. táblázat}

Magyar Természettudományi Múzeum óvodásoknak ajánlott múzeumpedagógiai foglalkozásai

(Forrás: saját összeállitás, http://www.nhmus.hu/hu/pedagogusoknak/foglalkozasok)

\begin{tabular}{|l|l|l|l|}
\hline \multicolumn{1}{|c|}{ Foglalkozás } & \multicolumn{1}{c}{ Foglalkozás tartalma } & \multicolumn{1}{c|}{$\begin{array}{c}\text { Ajánlott } \\
\text { korosztály }\end{array}$} & \multicolumn{1}{c|}{ Időtartam } \\
\hline $\begin{array}{l}\text { Természetbú- } \\
\text { vár-terem - A } \\
\text { kézbe vehető } \\
\text { múzeum }\end{array}$ & $\begin{array}{l}\text { A foglalkozás során a múzeumpedagó- } \\
\text { gusok megteremtik a szabad vizsgálódás } \\
\text { feltételeit: itt a megismerés folyamatába } \\
\text { valamennyi érzékszervet igyekeznek be- } \\
\text { vonni. A gyerekek megismerhetik a termé- } \\
\text { szet érdekességét és szépségét. }\end{array}$ & $\begin{array}{l}\text { Minden } \\
\text { korosztály } \\
\text { számára }\end{array}$ & $\begin{array}{l}\text { A korcso- } \\
\text { port igénye- } \\
\text { ihez alkal- } \\
\text { mazkodva } \\
45-60 \text { perc }\end{array}$ \\
\hline & \multicolumn{2}{l|}{} & \\
\hline
\end{tabular}

${ }^{6}$ Magyar Természettudományi Múzeum. Állandó kiállítások.http://www.nhmus.hu/hu/kiallitasok/allando_kiallitasok 


\begin{tabular}{|c|c|c|c|}
\hline $\begin{array}{l}\text { A korallzátony } \\
\text { világa }\end{array}$ & $\begin{array}{l}\text { A foglalkozáson résztvevők megismer- } \\
\text { kedhetnek a zátonyok színpompás pillan- } \\
\text { góhalaival, a feltűnő szépségű, ám annál } \\
\text { veszélyesebb tűzhallal is. Kiderül miről } \\
\text { kapták nevüket a doktorhalak, és hogy } \\
\text { mire használja a csipeszhal a valóban } \\
\text { csipeszre hasonlító száját. }\end{array}$ & \multirow[t]{2}{*}{$\begin{array}{l}\text { Óvodások, } \\
\text { alsósok } \\
\text { (4 évesektől } \\
10 \text { évesekig) }\end{array}$} & \multirow[t]{5}{*}{$\begin{array}{l}45 \text { perc } \\
\text { (Egyénileg } \\
\text { egyeztetve } \\
\text { életkortól } \\
\text { függően } \\
\text { változhat.) }\end{array}$} \\
\hline Erdőkerülő & $\begin{array}{l}\text { A foglalkozáson a hazai erdők lakóival } \\
\text { ismerkedhetnek meg a kicsik és nagyok. } \\
\text { A sünt, a fakopáncsot, a vaddisznót min- } \\
\text { den gyerek ismeri, de vajon tudják-e, mi } \\
\text { a különbség az őz és a szarvas között? A } \\
\text { múzeumi erdőkerülésen ilyen kérdésekre } \\
\text { keresik a válaszokat, kézbe vehető tár- } \\
\text { gyakkal és játékkal. }\end{array}$ & & \\
\hline Rovarlesen & $\begin{array}{l}\text { A foglalkozáson résztvevők kipróbálhatják } \\
\text { mire való a szarvasbogár rágója, hogyan, } \\
\text { mivel és miért „hegedül” a szöcske stb. Az } \\
\text { ismeretszerzést a sok-sok játék teszi igazi } \\
\text { élménnyé! }\end{array}$ & \multirow[t]{3}{*}{$\begin{array}{l}\text { Óvodások } \\
\text { alsósok } \\
\text { (nagycso- } \\
\text { portos óvo- } \\
\text { dásoktól } 10 \\
\text { évesekig) }\end{array}$} & \\
\hline $\begin{array}{l}\text { Mamutok és } \\
\text { társaik }\end{array}$ & $\begin{array}{l}\text { A mamutok világa, főleg a Jégkorszak } \\
\text { címü film megjelenése óta érdekli nagyon } \\
\text { a gyerekeket. Milyenek voltak valójában } \\
\text { a jégkorszak legismertebb állatai? Milyen } \\
\text { körülmények között, hogyan éltek az } \\
\text { ősemberek? A beszélgetést például sok } \\
\text { valódi maradvány (pl. barlangi medve láb- } \\
\text { szárcsontja, óriásszarvas agancstöredéke) } \\
\text { kézbeadásával teszik izgalmassá. }\end{array}$ & & \\
\hline A mi dínóink & $\begin{array}{l}\text { A legtöbb gyerek nagyon szereti a di- } \\
\text { noszauruszokat. A kis dinó-szakértők } \\
\text { megtudhatják azt is, hogy a Hun-ga-ro- } \\
\text { sza-u-rusz nem egy nyelvtörő, hanem egy } \\
\text { Magyarország területén feltárt dinoszau- } \\
\text { rusz neve. A foglalkozáson csontmásolato- } \\
\text { kat vehetnek kézbe a gyerekek. }\end{array}$ & & \\
\hline
\end{tabular}

Ahogy a múzeum által kínált múzeumpedagógiai programok is mutatják, a gyerekek már óvodáskorban meghatározó élményeket szerezhetnek egyegy természettudományos tapasztalat, kísérlet, megfigyelés során. Az így szerzett emlékek akár a gyermek későbbi érdeklődésére és a tantárgyakhoz való hozzáállására is kihathatnak. Számos kutatási eredmény is alátámasztja, hogy az érdeklődés felkeltése, illetve fenntartása erősebb, ha az tapasztalati tényen alapul, vagy emlékek, érzések füződnek a jelenséghez, játékhoz (Chalufour \& Worth, 2009). 


\section{Óvodások a Hetedhét Játékmúzeumban - A gyermeki lét: Játék- és mesevilág}

A székesfehérvári Hetedhét Játékmúzeum 2012-ben nyitotta meg kapuit a belváros egyik legszebb épületében, a Hiemer-Házban. A múzeum két állandó kiállítása a Moskovszky-gyüjtemény és a Réber-gyüjtemény. A jelentős gyűjtőmunkának köszönhetően a látogatók különleges babaszobákban fedezhetik fel a különböző korok és stílusok enteriőrjeit. A múzeum egyik állandó kiállítása a Moskovszky-gyüjtemény, ami a hazai játékmuzeológia legjelentősebb anyaga, a 18-19. századi polgári játékokból összeállított, túlnyomórészt babaszobákba rendezett gyüjteményét mutatja be (Bernáth, 2016). A Moskovszky-gyüjtemény sajátos, egyedi vonásai közé tartozik, hogy a miniatűr tárgyak hozzáadott látványelemek nélkül képesek több generáció számára is meghatározó, maradandó élményt nyújtani (Nagy, 2013). A múzeum másik állandó kiállítása Réber László (1920-2001) Munkácsy-díjas grafikusművész, illusztrátor, karikaturista állandó kiállítása. A kiállítás a népszerủ meseillusztrációiból és felnőtteknek szóló grafikáiból válogat (Bernáth, 2016).

\section{Múzeumpedagógiai foglalkozások óvodásoknak}

A múzeum két állandó kiállítása a gyermeki lét varázslatos világába kalauzolja a felfedező kicsiket és nagyokat. A múzeumpedagógiai foglalkozások célja a komplexitást, kreativitást elősegítő helyzetek megteremtése. Az alkotófolyamatban, az élményszintű újra átélés, a játék, a szabadság, folyamatos önmegismerés, örömszerzés, játékosság, sikerélmény, valamint a közösségi élményen keresztüli megélések, megerősítése történik. A múzeum szakképzett kollégái a kortárs múzeumpedagógiai módszerek széles palettáját használják, amellyel élménnyé teszik a tudásszerzést óvodás kortól középiskolás korig. Interaktív foglalkozásaik segítenek megismerni a múzeum sokszínű gyűjteményeit, lehetőséget biztosítanak a látogatóknak arra, hogy a kiállításaikhoz kapcsolódóan értékes ismereteket és tapasztalatokat szerezzenek ${ }^{7}$. A múzeum óvodásoknak ajánlott múzeumpedagógiai foglalkozásai a 2. táblázatban olvashatóak.

${ }^{7}$ Szent István Király Múzeum-Múzeumpedagógia. https://szikm.hu/muzeumpedagogia/ 
2. táblázat

Hetedhét Játékmúzeum óvodásoknak ajánlott múzeumpedagógiai foglalkozásai (Forrás: saját összeállitás, https://www.deakgyujtemeny.hu/site_hh.cgi?a=rovatEid=hh_ muzped)

\begin{tabular}{|c|c|c|}
\hline Foglalkozás & Foglalkozás tartalma & Ajánlott korosztály \\
\hline \multicolumn{3}{|c|}{ Múzeumpedagógiai foglalkozások a Moskovszky-gyüjteményben } \\
\hline $\begin{array}{l}\text { Egy nap a ba- } \\
\text { baházban }\end{array}$ & $\begin{array}{l}\text { A gyerekek meglátogathatják Zsuzskát és Fruskát az } \\
\text { otthonukban! Mennyi szép bútor, apró csecsebecse! } \\
\text { De jó lenne berendezni a saját babaházunkat! }\end{array}$ & \multirow[t]{2}{*}{$\begin{array}{l}\text { Óvodás (vak és lá- } \\
\text { tássérült gyermekek } \\
\text { számára is kérhető) }\end{array}$} \\
\hline $\begin{array}{l}\text { Játék(os) állat- } \\
\text { világ }\end{array}$ & $\begin{array}{l}\text { Teddy izgatottan várja, hogy egy egész seregnyi } \\
\text { kisgyereknek mesélhessen legutóbbi kalandjairól. } \\
\text { A gyerekek egy igazi Teddy mackóval játszhatnak. }\end{array}$ & \\
\hline Babazsúr & $\begin{array}{l}\text { Fruskának születésnapja van. Itt az ünnepi } \\
\text { uzsonna ideje! A gyerekek a porceláncsészés } \\
\text { gyermekzsúrok világába kerülnek, ahol lesznek } \\
\text { vendégvárók és vendégek, majd kortyolhatnak a } \\
\text { képzeletbeli teából. }\end{array}$ & \multirow[t]{2}{*}{ Óvodás } \\
\hline Lídia titka & $\begin{array}{l}\text { Lídia az utóbbi időben csak Huszárral, az öreg } \\
\text { hintalóval foglalkozik nagy titokzatosan. Vajon } \\
\text { miért? A kislány kíváncsi porcelánbabái a végére } \\
\text { járnak a dolognak. }\end{array}$ & \\
\hline Maszkabál & $\begin{array}{l}\text { Közeleg a bál! Ideje készülődni! Válasszuk ki a } \\
\text { megfelelő ruhát és mulassunk együtt baba-módra! } \\
\text { Az ovis gyerekek játékbabákká változnak, és száz } \\
\text { évet ugranak vissza az időben... }\end{array}$ & \multirow[t]{3}{*}{ Óvodás } \\
\hline Vármese & $\begin{array}{l}\text { Grexa várának legmagasabb tornyában egy } \\
\text { királylány raboskodik. A várat azonban marcona } \\
\text { ólomkatonák őrzik. Csatára fel! Vajon kiszabadul } \\
\text { a hercegkisasszony? A foglalkozás végén katonák- } \\
\text { ká, királylányokká és építőmesterekké változnak } \\
\text { a gyerekek. }\end{array}$ & \\
\hline Szatócsbolt & $\begin{array}{l}\text { Vajon mi mindent lehet kapni egy réges-régi } \\
\text { boltban? No, és ki lesz az eladó, s ki a vásárló? A } \\
\text { bevásárlólisták már elkészültek, itt az idő, hogy } \\
\text { megteljenek a kosarak! }\end{array}$ & \\
\hline \multicolumn{3}{|c|}{ Múzeumpedagógiai foglalkozás a Réber László kiállításban } \\
\hline $\begin{array}{l}\text { Szegény Dzsoni } \\
\text { és Ârnika nyo- } \\
\text { mában }\end{array}$ & $\begin{array}{l}\text { Vajon hol lehet Árnika királykisasszony? És hogy } \\
\text { siet a segítségére Szegény Dzsoni? A játék során } \\
\text { feltárul a mese! }\end{array}$ & Óvodás \\
\hline
\end{tabular}


Az adott babaszobákhoz közvetlenül kapcsolódó interaktív játékok és feladatok (például kirakók, rajzolós feladvány, érzékszerveket „dolgoztató” feladatok, lapozható minikönyvek) a vitrinek aljába rejtett kihúzható fiókokban találhatók, amely a felfedezés lehetőségét biztosítja (Nagy, 2013). A múzeum gyűjteményei között sok múltbeli tárgyat, babákat, játékszereket találhatunk, a múzeumban a játék, kulturális és kultúra-áthagyományozó szerepe egyaránt jelentős (Tancz, 2004).

\section{Természettudomány és játék}

A Magyar Természettudományi Múzeum és a Hetedhét Játékmúzeum óvodásoknak szóló múzeumpedagógiai programját összehasonlítva látható, hogy a két múzeum profilja, kiállított tárgyai eltérőek, azonban mind a kettő múzeum biztosít óvodáskorú gyerekeknek programokat, kiállításokat, színvonalas múzeumpedagógiai foglalkozások keretén belül. Míg a Magyar Természettudományi Múzeum egy természettudományos profilt képvisel, addig a Hetedhét Játékmúzeum az óvodáskorú gyerekekhez közel álló játék és mese vonalán szervezi múzeumi programjait. (3. táblázat)

\section{3. táblázat}

Magyar Természettudományi Múzeum és a Hetedhét Játékmúzeum összehasonlítása, összegzö táblázat

(Forrás: saját összeállítás; Lord, 2001. p. 22; Magyar Természettudományi Múzeum hivatalos honlapja http://www.nhmus.hu/; Hetedhét Játékmúzeum honlapja, http://www.deakgyujtemeny.hu/site_hh.cgi; 363/2012. (XII. 17.) Kormámy rendelet az Óvodai nevelés országos alapprogramjáról.)

\begin{tabular}{|c|c|c|}
\hline & $\begin{array}{c}\text { Magyar Természettudományi } \\
\text { Múzeum }\end{array}$ & Hetedhét Játékmúzeum \\
\hline $\begin{array}{l}\text { Múzeum tí- } \\
\text { pusa }\end{array}$ & $\begin{array}{c}\text { Természettudományos ismeretek } \\
\text { közvetitése }\end{array}$ & $\begin{array}{c}\text { Játékszerek és enteriörök bemu- } \\
\text { tatása }\end{array}$ \\
\hline $\begin{array}{l}\text { Múzeumpeda- } \\
\text { gógiai foglal- } \\
\text { kozás tartalma }\end{array}$ & $\begin{array}{l}\text { A kiállított és bemutatott eredeti } \\
\text { és mütárgyak segítik a környezeti } \\
\text { jelenségek, tudományterületek } \\
\text { alaposabb megismerését, feldolgo- } \\
\text { zását. }\end{array}$ & $\begin{array}{l}\text { A kiállított és bemutatott mütár- } \\
\text { gyak a játék segítségével segítik a } \\
\text { régi korok (gyermek)kultúrájának } \\
\text { alaposabb megismerését, feldolgo- } \\
\text { zását. }\end{array}$ \\
\hline $\begin{array}{l}\text { Kiállított tár- } \\
\text { gyak }\end{array}$ & Eredeti tárgy és hiteles másolat & Mütárgyak \\
\hline $\begin{array}{l}\text { Megértési } \\
\text { mód }\end{array}$ & Játék, felfedezéses tanulás & Játék, mese (narratíva) \\
\hline
\end{tabular}




\begin{tabular}{|l|l|l|}
\hline $\begin{array}{l}\text { Múzeumpe- } \\
\text { dagógiai mód- } \\
\text { szerek }\end{array}$ & $\begin{array}{l}\text { Játék, szituáció-játék, irányított } \\
\text { megfigyelés, gyermeki kérdésekre, } \\
\text { válaszokra épülő ismeretszerzés }\end{array}$ & $\begin{array}{l}\text { Játék, mese; drámajáték, szerepjá- } \\
\text { ték; utánzás }\end{array}$ \\
\hline $\begin{array}{l}\text { Óvodai neve- } \\
\text { lés lehetséges } \\
\text { alkalmazási } \\
\text { területe }\end{array}$ & $\begin{array}{l}\text { Külső világ tevékeny megismerése; } \\
\text { zöld jeles napok; projekt tartalmú } \\
\text { óvodai tevékenységek }\end{array}$ & $\begin{array}{l}\text { Játék, szabad játék; művészeti } \\
\text { nevelés; projekt tartalmú óvodai } \\
\text { tevékenységek pl. mese projekt; ol- } \\
\text { vasóvá-nevelés; esztétikai nevelés; } \\
\text { drámapedagógia; erkölcsi nevelés }\end{array}$ \\
\hline $\begin{array}{l}\text { Értékátadás } \\
\text { tartalma }\end{array}$ & Környezettudatos magatartás & Gyermekkultúra, hagyományőrzés \\
\hline
\end{tabular}

\section{Az empirikus vizsgálat bemutatása}

\section{A kutatás célja, hipotézisei}

A kutatás célja a két múzeumban folyó múzeumpedagógiai munka megismerése, fókuszban a múzeum által biztosított és szervezett múzeumpedagógiai programok, kiállítások lehetőségeinek feltárása egy óvodáskorú gyermek nevelésében, tanulásában.

A kutatási kérdések az óvodáskorú gyermekek múzeumi tanulására vonatkoztak: 1. Hogyan valósul meg a Magyar Természettudományi Múzeum, és a Hetedhét Játékmúzeum múzeumi kiállítás anyagának feldolgozása egy óvodás korú gyermek látogatása során az elérhető múzeumpedagógiai foglalkozásokkal? 2. Hogyan valósul meg a Magyar Természettudományi Múzeumban, és a Hetedhét Játékmúzeumban az óvodások múzeumi tanulása a múzeum, illetve a kiállítás területén elhelyezett játékok, táblák segítségével? 3. Hogyan jelennek meg az óvodai nevelés alapelvei a múzeumokban, az óvodásoknak szóló tevékenységek során? 4. Hogyan alkalmazkodik a Magyar Természettudományi Múzeum és a Hetedhét Játékmúzeum az óvodáskorú gyermek életkori sajátosságaihoz?

A kutatás során a következő hipotéziseket fogalmaztam meg: 1. A vizsgált múzeumokban tevékenykedő múzeumpedagógusok szakképzettsége lehetővé teszi az óvodáskorú gyermek múzeumi tanulását. 2. A vizsgált múzeumokban a múzeumpedagógusok tudatosan készülnek fel az óvodásoknak tartott múzeumpedagógiai foglalkozásokra, pontos ismereteik vannak az óvodások életkori sajátosságairól.

\section{A vizsgálat módszerei}

\section{A kutatási módszerek}

Kutatásom során kvalitatív kutatási módszereket alkalmaztam, így nem a számszerű adatok bemutatása, általános érvényességű megállapítások megalkotása volt a célom, hanem a kutatásom témájában mélyebb, árnyaltabb ismeretek megszerzése, melyhez kis elemszámú mintán történt az adatfel- 
vétel. A kutatás során a különböző szabályok mozgatórugóinak feltárása, a szabályszerűségek megismerése és megértése volt fókuszban. Ebben az esetben a kutatás célcsoportjának gondolkodása, tapasztalatai, az óvodások múzeumi tanulásának, mint jelenségnek mély rétegeinek feltárására a „miértek” megértése volt a cél. Emiatt a kutatás során magas a szubjektivitás lehetősége, amely befolyásolja a megbízhatóságot (Szabolcs, 2011).

A kutatáshoz szükséges adatok felvételéhez online írásbeli kikérdezést, és egyéni interjút alkalmaztam. Az írásbeli kikérdezéshez saját összeállítású kérdőívet használtam, amit online közösségi platformokon, illetve e-mailes és személyes megkeresésen keresztül juttattam el a kutatásban résztvevőknek. Az egyéni interjú során saját összeállítású, félig strukturált kérdéssort alkalmaztam, amely tartalmazott zárt és nyílt végü kérdéseket is. Az egyéni interjú vizsgálatot a kutatásban résztvevő két múzeumban dolgozó múzeumpedagógusokkal végeztem el.

\section{Az adatok feldolgozásának módszerei}

A szocio-demográfiai adatok elemzésénél leíró statisztikát alkalmaztam, hogy képet kapjak a kutatásban résztvevő személyek összetételéről. Az online kérdőíves vizsgálatban erre vonatkozóan vizsgáltam a kutatásban résztvevők nemét, életkorát; legmagasabb iskolai végzettséget; a település típusát, ahol a kitöltés idejében dolgozott; a pedagógusi pályán eltöltött időt, valamint a kitöltés idejében betöltött pozíciót. A vizsgálat során kapott adatokat Excel-táblázatban összesítettem és dolgoztam fel.

Az interjúkról készült átiratok elemzéséhez tartalomelemzést használtam. Az elméleti megalapozásra építve (Koltai, 2011; Nahalka, 2002; Kolosai, 2016; Takács \& Csimáné Pozsegovics, 2016a) az interjúk értékeléséhez saját összeállítású elemzési keretet állítottam fel. (1. ábra) 


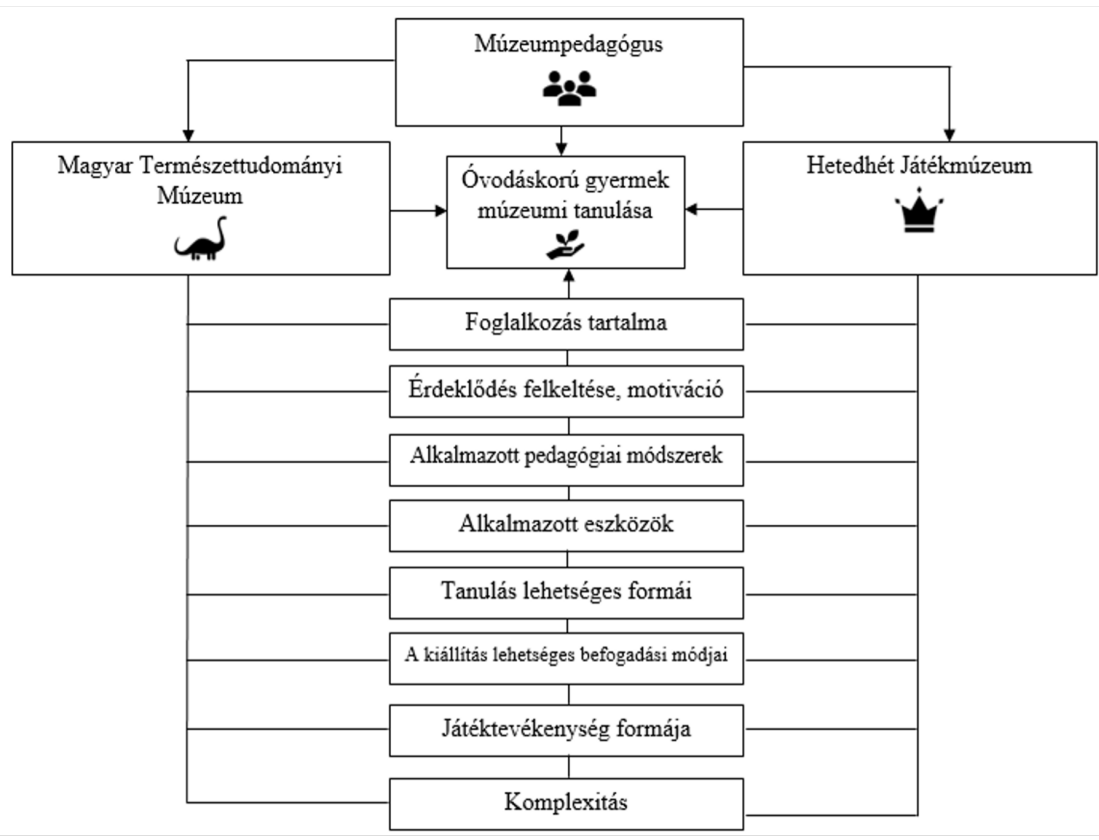

1. ábra

Elemzési keret az interjúk elemzéséhez

Az elemzési keret az óvodások múzeumi tanulását állítja középpontba, az Óvodai nevelés országos alapprogramja ${ }^{8}$ alapján és az óvodások múzeumi tanulásának jellemzőit figyelembevéve (Kolosai 2017; Koltai, 2011; Körmöci, 2002; Nahalka, 2002). Az elemzési keret két fő részből áll (Magyar Természettudományi Múzeum; Hetedhét Játékmúzeum), illetve a fó részhez tartozó 9 elemből álló szempontsorból, amely a múzeumban folyó múzeumpedagógiai munka alapján az óvodások múzeumi tanulásának lehetőségeit tárja fel. A fö részhez tartozó szempontsor elemei a következőek: 1. a foglalkozás tartalma megmutatja, hogy a múzeumpedagógiai foglalkozás milyen tartalom, illetve témakör mentén szerveződik, és hogy ezek a tartalmak megfelelő motivációt ébresztenek-e egy óvodáskorú gyermekben. 2. A motiváció ismeretet ad arról, hogy a múzeumpedagógus hogyan és mivel tudja a gyermek érdeklődését felkelteni és fenntartani, amely a tanulás szempontjából fontos. 3. Az alkalmazott pedagógiai módszerek, illetve 4. az alkalmazott eszközök a múzeumpedagógiai munka módszertani kidolgozottságára, és ennek gyakorlati alkalmazására, múzeumpedagógiai eszközök meglétére vonatkoznak.

8363/2012. (XII. 17.) Kormány rendelet az Óvodai nevelés országos alapprogramjáról. 
5. A tanulás lehetséges formáit a múzeumpedagógus által kezdeményezett tevékenységi formákban megvalósuló tanulást, felfedezést és ismeretszerzést tárja fel. 6. A kiállítás lehetséges befogadási módjai ismerteti a múzeumi tanulás lehetséges módjait az óvodáskorú gyermek függvényében (Lord, 2001). 7. A játéktevékenység megmutatja, hogy a múzeumpedagógus milyen játékokat alkalmaz múzeumpedagógiai foglalkozásai során. 8. A komplexitás a múzeumpedagógiai foglalkozás óvodai nevelésbe való illeszthetőségét, illetve a különböző nevelési területek összekapcsolásának lehetőségét tárja fel. 9. A múzeumpedagógus felkészültsége pedig megmutatja, hogy képes-e a múzeumpedagógus az óvodások életkori sajátosságaira építve alkalmazni és megvalósítani a tervezett múzeumpedagógiai foglalkozásokat. A múzeumpedagógus felkészültsége alapvetően meghatározza azt, hogy a játék és tanulás, mint nevelési eszköz hatékony legyen.

\section{Kutatás időpontja és a vizsgálati személyek}

Az adatgyüjtésre 2020. április első felében került sor. A mintavétel alapsokasága minden olyan általam felkért, a kutatásban önként résztvevő múzeumpedagógus, muzeológus, óvodapedagógus vagy óvodapedagógus hallgató, aki munkája során a budapesti Magyar Természettudományi Múzeumban és/vagy a székesfehérvári Hetedhét Játékmúzeumban: részt vett saját óvodai csoportjával óvodáskorú gyermekek számára szervezett múzeumpedagógiai foglalkozáson; kiállításon és/vagy látott óvodáskorú gyermekek számára tartott múzeumpedagógiai foglalkozást, kiállítást és/vagy tartott óvodáskorú gyermekek számára múzeumpedagógiai foglalkozást.

\section{Minta}

A vizsgálatban összesen 54 fő pedagógiai munkát végző személy vett részt, amely a kutatás szempontjából értékelhetőnek mondható. A nemek szerinti eloszlás alapján 51 nő, 2 férfi töltötte ki a kérdőívet, illetve 1 kitöltő nem adott meg nemére vonatkozó információt. A kitöltők 85\%-a óvodapedagógus (46 fö), 7,5\%-a múzeumpedagógus (4 fó) és 7,5\% (4 fö) egyéb foglalkozási kategóriába sorolta magát. A település típusát tekintve 29 fö a fóvárosban, 10 fó városban, 9 fö megyeszékhelyen, 1 fó nagyközségben, 1 fö községben és 1 fó egyéb településen végzi pedagógiai munkáját. A kitöltők között akadt pályakezdő és több mint 10 éve pályán lévő pedagógus is. (4. táblázat) 
4. táblázat

A vizsgálatban résztvevők szocio-demográfiai jellemzői $(N=54)$

\begin{tabular}{|c|c|c|c|c|c|c|c|c|}
\hline \multirow[t]{2}{*}{$\begin{array}{l}\text { Alapvető jel- } \\
\text { lemzők }\end{array}$} & \multicolumn{2}{|c|}{$\begin{array}{l}\text { Múzeumpeda- } \\
\text { gógus }\end{array}$} & \multicolumn{2}{|c|}{$\begin{array}{l}\text { Óvodapeda- } \\
\text { gógus }\end{array}$} & \multicolumn{2}{|c|}{ Egyéb } & \multicolumn{2}{|c|}{ Teljes minta } \\
\hline & $\mathrm{n}$ & $\%$ & $\mathrm{n}$ & $\%$ & $\mathrm{n}$ & $\%$ & $\mathrm{n}$ & $\%$ \\
\hline \multicolumn{9}{|l|}{ Gender } \\
\hline Nő & 2 & 3.7 & 46 & 85 & 3 & 0.5 & 51 & 94.4 \\
\hline Férfi & 2 & 3.7 & 0 & 0 & 0 & 0 & 2 & 3.7 \\
\hline Egyéb & 0 & 0 & 0 & 0 & 1 & 1.9 & 1 & 1.9 \\
\hline Beosztás & 4 & 7.5 & 46 & 85 & 4 & 7.5 & 54 & 100 \\
\hline \multicolumn{9}{|l|}{ Település típusa } \\
\hline Főváros & 3 & 0.5 & 28 & 51.9 & 0 & 0 & 31 & 57.4 \\
\hline Megyeszékhely & 1 & 1.9 & 7 & 13 & 0 & 0 & 8 & 14.8 \\
\hline Nagyközség & 0 & 0 & 2 & 3.7 & 0 & 0 & 2 & 3.7 \\
\hline Község & 0 & 0 & 1 & 1.9 & 0 & 0 & 1 & 1.9 \\
\hline Város & 0 & 0 & 8 & 14.8 & 0 & 0 & 8 & 14.8 \\
\hline Egyéb & 0 & 0 & 0 & 0 & 4 & 7.4 & 4 & 7.4 \\
\hline \multicolumn{9}{|c|}{ Pedagóguspályán eltöltött idő } \\
\hline 1-2 év & 1 & 1.9 & 8 & 14.8 & 0 & 0 & 9 & 16.7 \\
\hline 3-5 év & 1 & 1.9 & 10 & 18.5 & 0 & 0 & 11 & 20.4 \\
\hline 5-10 év & 1 & 1.9 & 16 & 29.6 & 0 & 0 & 17 & 31.5 \\
\hline 10 évnél több & 0 & 0 & 12 & 22.2 & 0 & 0 & 12 & 22.2 \\
\hline Egyéb & 1 & 1.9 & 0 & 0 & 4 & 7.4 & 5 & 9.3 \\
\hline
\end{tabular}

\section{Eredmények}

\section{Kérdöíves vizsgálat tapasztalatai}

A vizsgálatban részt vett óvodapedagógus személyek (46fö) pedagógiai munkájáról elmondható, hogy szivesen viszik óvodai csoportjukat múzeumba: 24 fó (44,4\%) a Magyar Természettudományi Múzeumot, 8 fö (14,8\%) a Hetedhét Játékmúzeumot, 5 fö $(9,3 \%)$ mind a kettő múzeumot és 9 fö (16,7\%) pedig az egyéb lehetőséget jelölte. Ugyanakkor a mintába került óvodapedagógusok közül 9 fö (16,7\%) havonta, 15 fö $(27,8 \%)$ pedig évente viszi a Magyar Természettudományi Múzeumba óvodai csoportját. A Hetedhét Játékmúzeum látogatását tekintve a mintába került óvodapedagógusok bevallása alapján 3 fö (5,6\%) havonta, 5 fó (9,3\%) pedig évente viszi múzeumba a gyerekeket, ami kicsi arány. (5. táblázat) 
5. táblázat

A vizsgálatban résztvevő óvodapedagógusok óvodai csoportjukkal való múzeumlátogatásának száma és gyakorisága

Megjegyzés. Teljes minta $N=54$ fó. Vizsgálatban résztvevő óvodapedagógusok száma $N=46$ fó MT: Magyar Természettudományi Múzeum, HJ: Hetedhét Játékmúzeum

\begin{tabular}{|l|c|c|c|c|c|c|c|c|c|c|}
\hline $\begin{array}{l}\text { Alapvető jellem- } \\
\text { zők }\end{array}$ & \multicolumn{2}{c}{$\begin{array}{c}\text { MT Múze- } \\
\text { um }\end{array}$} & \multicolumn{2}{c|}{$\begin{array}{c}\text { HJ Múze- } \\
\text { um }\end{array}$} & $\begin{array}{c}\text { Mindkettő } \\
\text { múzeum }\end{array}$ & \multicolumn{2}{c|}{ Egyéb } & \multicolumn{3}{|c|}{$\begin{array}{c}\text { Teljes } \\
\text { minta }\end{array}$} \\
\hline $\begin{array}{l}\text { Múzeumlátogatás } \\
\text { helye }\end{array}$ & 24 & 44.4 & 8 & 14.8 & 5 & 9.3 & 9 & 16.7 & 46 & 85 \\
\hline Múzeumlátogatás gyakorisága & & & & & & & & \\
\hline Hetente & 0 & 0 & 0 & 0 & 0 & 0 & 0 & 0 & 0 & 0 \\
\hline Havonta & 9 & 16.7 & 3 & 5.6 & 0 & 0 & 0 & 0 & 12 & 22.2 \\
\hline Évente & 15 & 27.8 & 5 & 9.3 & 0 & 0 & 0 & 0 & 20 & 37 \\
\hline Egyéb & 0 & 0 & 0 & 0 & 0 & 0 & 14 & 25.9 & 14 & 25.9 \\
\hline
\end{tabular}

Összefüggés mutatható ki a gyermekkori múzeumi élmények és a felnőttkori múzeumlátogatási szokásrendszer között. Azok az óvodapedagógusok, akik már gyermekként is látogattak múzeumot (volt részük múzeumi élményben), felnőttként is szívesen igénybe veszik (óvodai csoportjukkal együtt!) a múzeum kínálta lehetőségeket, múzeumpedagógiai foglalkozásokat. Ez a teljes minta 59,3\%-a (32 fö). „Nagyon szerettünk testvéremmel múzeumba járni. Rengeteg élményünk kötődik a múzeumi látogatásainkhoz. A Természettudományi Múzeum kiskorunk óta ismert, és azóta szinte minden zeg-zugát bejárt pedagógusok lettünk és szivesen visszük a csoportjainkat."

A Magyar Természettudományi Múzeum múzeumpedagógiai foglalkozásai közül a legtöbb óvodapedagógus (18fö) a Természetbúvár terem, Rovarlesen, és az Erdőkerülő foglalkozáson vett már részt óvodai csoportjával. Emellett még említették a Beporzók ünnepe, Madarak és fák napja, Föld napja, Víz világnapja múzeumi programokat, amelyet már igénybe vettek óvodai csoportjukkal. A Hetedhét Játékmúzeumban Lídia titka (mese), Szegény Dzsoni és Árnika nyomában, Vármese, és Maszkabál múzeumpedagógiai foglalkozásokat említették legtöbbször az óvodapedagógusok, amelyen már részt vettek óvodai csoportjukkal.

Az óvodapedagógusok 85\%-a szerint a múzeumlátogatás lehetőségét már óvodáskorban biztosítani kell, mivel a gyermeknek szüksége van arra, hogy az óvodai nevelés során minél több ismerethez jusson. A múzeumpedagógusok szintén hasonlóan vélekednek arról, hogy már óvodáskorban helye van a múzeumlátogatásnak, amely segíti a gyermek tanulását, tapasztalatszerzé- 
sét. „A mai ingerekkel túlterhelt, világban minden gyermeknek szüksége van arra, hogy valódi értékeket lásson, érzékeljen, tapasztaljon. A múzeum és az ott dolgozó szakemberek érzékenyen, a mütárgyak felöl közelitenek a gyermekekhez, az értékközvetitést szem elött tartva. Sok, nagyon sok ma már a gyermekprogram, de a múzeumpedagógia sosem lehet csak egy ezek közül. A maga játékos eszközeivel egyszerre tanit, értéket ad és szemléletet formál."

\section{Múzeumpedagógusokkal készített interjú tapasztalatai}

A Magyar Természettudományi Múzeumban 6 féle múzeumpedagógiai program érhető el óvodáskorú gyermekek számára. A foglalkozások tartalmát tekintve elmondható, hogy elsősorban természettudományos élményt, a felfedezés élményét, a kutatás és kíváncsiság kielégítésének élményét nyújtja a korosztálynak megfelelő módon és eszközökkel. A megkérdezett múzeumpedagógusok a következő hasonlatokkal, metaforákkal írták le a múzeumot: „ $A$ természettudományok temploma”, „A tudomány kissé poros fellegvára”, „Természettudományos kincsesbánya kicsiknek, nagyoknak".

A múzeumpedagógiai foglalkozások célja, hogy a múzeum kiállításaiban bemutatott tárgyakat, jelenségeket, tudományterületeket alaposabban megismerjék a múzeumba látogatók. Az érdeklődés felkeltése, a gyerekek motivációja mindig az adott témának megfelelő eszközökkel és játékkal történik. Például a Természetbúvár teremben minden kézbe vehető, megérinthető, megszagolható, ezért is nevezik A kézbe vehető múzeumnak. Az Erdőkerülö múzeumpedagógiai foglalkozáson kézbe vehető például egy őzkoponya, sün- és fakopáncs-preparátum, amelyeket a gyerekek máskülönben nem, vagy csak messziről egy pillanatra láthatnak a természetben.

A sokszínü foglalkozások óvodai csoportoknál, csoportos tevékenység formájában valósulnak meg. Az ismeretátadás legtöbbször frontálisan történik, ugyanakkor a múzeumpedagógusok igyekeznek különböző játékokat - mozgás; rajz; érzékszervet megmozgató, bevonó játékok; szerepjáték, drámapedagógia; kísérletezés; vetélkedő (például szimatszondaverseny); felfedezés; mese - alkalmaznak a foglalkozás közben.

A tevékenységek során a múzeumpedagógusok az óvodások múzeumi tanulását a gyermeki kérdésekre, válaszokra épülő ismeretszerzéssel segítik elő, illetve biztosítják az irányított megfigyelés, tapasztalatszerzés, felfedezés élményének lehetőségét. A múzeumpedagógusok elmondása alapján mindent elkövetnek annak érdekében, hogy az ide látogató óvodás gyerekek ne csak játszva tanuljanak, hanem tanulva játszanak, és a természettudományos tapasztalatszerzéshez pozitív élményt kapcsoljanak. „Mivel nincs ilyen irányú végzettségem és tudásom, nem szoktam a gyerekekkel mondókákat mondani, énekelni, és nem szoktam mászatni, szaladgáltatni a gyerekeket (hely sem nagyon van erre). Ez utóbbiakat hiányosságként élem meg és igyekszem mással ellensúlyozni," mint például ismert mesék föszereplőinek felidézése, kísérletezés vagy szerepjáték. 
A beszámolók alapján a múzeumpedagógusok tudatosan készülnek fel egy-egy foglalkozásra, legyen az akár egy állandó- vagy egy új foglalkozás. Igyekeznek az adott korosztály életkori sajátosságainak megfelelő programot, foglalkozást összeállítani, összekapcsolva a múzeumban elérhető tárgyi eszközökkel. „Minden foglalkozást az adott korcsoport igényeihez igazitjuk, tehát hogyha egy óvodás csoportnak készitünk foglalkozást, akkor nyilván mozgásos feladatokkal, játékokkal készülünk. Tudjuk, hogy ők azért nem birnak el annyit egyhelyben ülve, mint mondjuk egy alsó tagozatos diák."

A tudatos tervezés érdekében a múzeumpedagógusok figyelembe veszik a korosztály összetételét (ami elmondásuk alapján még óvodáskoron belül is számít!), milyen információkat szeretnének átadni és azt milyen eszközökkel érik el, illetve milyen módon valósítják meg a kitüzött céljaikat. „Ahány gyerek, annyiféle hozzáállás, annyiféle lelkiállapot. Ez csak a helyszinen derül ki. Minden korosztálynál alapvetöen fontos, hogy mennyire van felvértezve, elkészülve „a múzeumi élményszerzéses tanulásra”. „Sajnos, ha a pedagógus nem készíti fel a gyerekeket arra, hogy mire számithatnak, jóval nehezebb a múzeumpedagógus dolga is."

A Hetedhét Játékmúzeumban összesen 8 féle múzeumpedagógiai program érhető el óvodáskorú gyerekek számára. A foglalkozások tartalmát tekintve elmondható, hogy elsősorban a játék és a gyermeki lét varázslatos világának élményét nyújtja a korosztálynak megfelelő módon és eszközökkel. A megkérdezett múzeumpedagógus a következő hasonlatokkal, metaforákkal írta le a múzeumot: „a nyugalom szigete”; „otthon, új, biztonság, család, mosoly.”

A múzeumpedagógiai foglalkozások célja a komplexitást, kreativitást elősegítő helyzetek megteremtése. Az alkotófolyamatban, az élményszintü újraélés, a játék, a szabadság, folyamatos önmegismerés, örömszerzés, játékosság, sikerélmény, valamint a közösségi élményen keresztüli megélések megerősítése történik. A foglalkozásokon a Moskovszky és Réber Gyüjtemény mesés és játékos világába nyerhet a látogató betekintést.

Az érdeklődés felkeltése, a gyerekek motivációja mindig az adott témának megfelelő játékokkal, mesés történetekkel és demonstrációs eszközökkel valósul meg. Például a Lídia titka címủ mese története a múzeumban kiállított tárgyakhoz kapcsolódva teremti meg a felfedezés és a játék élményét. „A foglalkozáson játszott játék vagy egy-egy demonstrációs eszköz nem veheti át a mütárgy központi helyét, csupán kiegészitésként szolgálhat annak mélyebb megértéséhez."

A mesés-játékos foglalkozások az óvodai csoportoknál csoportos tevékenység formájában valósulnak meg. „Fontos, hogy a gyerekeknek legyen lehetôségük szabadon felfedezni a kiállitást, bizva bennük, hogy képesek érdeklödésük, saját aktuális állapotuknak megfelelöen a tárgyakat megvizsgálni, nem "rendetlenkedni” ehelyett. Ehhez adhatunk támpontokat, például keressenek nekik tetszö sárga színü tárgyakat, keressék meg a kedvenc állatukat vagy, hogy ők melyik babaszobában költenének el egy születésnapi uzsonnát." „Ügy vélem, hogy ha a gyerekek szivesen vesznek részt a játékban és kellöen motiváltak, akkor semmiféle rendetlenkedés nem tapasztalható." 
A múzeumpedagógiai tevékenység alapja a játék és a mese. Általában egy kerettörténet szerint halad végig a tevékenység, a múzeumpedagógus által kiválasztott, és a hozzá kapcsolódó a múzeumban kiállított tárgyakon keresztül: játszva, beszélgetve, teret hagyva a gyermekek fantáziájának, önálló gondolataiknak. A foglalkozás végén a gyermekeknek mindig van lehetőségük a szabad játékra és önálló felfedezésre.

$\mathrm{Az}$ ismeretátadás minél több érzékszerv megmozgatásával és a mese segítségével történik. A tevékenységek során a múzeumpedagógus szem előtt tartja az óvodás korosztályt megérintő, az életükben szerepet játszó témákat - például állatok, fözőcskézés, huszárok - amelyet figyelembe vesz a foglalkozás tervezésénél. A játékmúzeum kiállításának tárgyai maximálisan kapcsolódnak a gyermekek érdeklődéséhez. A múzeumpedagógus elmondása alapján az óvodásoknak tervezett foglalkozás esetében az óvodában is alkalmazott módszereket alakítja múzeumban megvalósított foglalkozásokhoz. Ezek többek között a bemutatás (kiállított tárgyakat, demonstrációs eszközöket); beszélgetés; magyarázat (új kifejezések, ismeretlen szavak, összefüggések); megfigyelés (kiállítás tárgyait); szemléltetés (demonstrációs eszközzel, képekkel); kérdve kifejtés és a kísérletezés (például mérés autentikus rézmérlegen).

A múzeumpedagógus a foglalkozások tervezésénél nem csak módszertani, hanem gyakorlati szempontokat, illetve az óvodások szükségleteit is figyelembe veszi, mint például hány gyermek fér oda egy-egy vitrin elé; legyen játék, sok mozgás, minél több érzékszervi élmény: „Legyen a foglalkozás végén olyan szabad játék, mely során a gyerekeknek lehetöségük van a megélt élményeket játékká formálni, autentikus játéktárgyakat megérinteni, olyan játéktárgyakkal játszani, melyekkel manapság már keveset találkoznak."

\section{Konklúzió}

A kutatásban résztvevő múzeumpedagógusok, illetve óvodapedagógusok véleményei, tapasztalatai, vélekedései alapján elmondható, hogy a Magyar Természettudományi Múzeum és a Hetedhét Játékmúzeum az óvodai nevelést kiegészítő, tudományos és kulturális helyszín, amely nem csak játékot, de az óvodáskori tanulás egyik lehetséges helyszínét is biztosítja az óvodáskorú gyermekek számára. A múzeumpedagógiai foglalkozásokon a gyermek megtapasztalhatja, hogy a múzeum egy olyan hely, ahol jó lenni, hiszen biztonságos környezetben, szabadon játszhat. A múzeumi foglalkozások alapja a múzeumi gyüjteményhez kapcsolódó ismeretanyag átadása pedagógiai eszközök segítségével, és ezzel felelősségteljes, a múlt emlékeit és a természetet tisztelö, óvó, és azok érdekében cselekvőképes felnőttek nevelése (Koltai, 2011). 


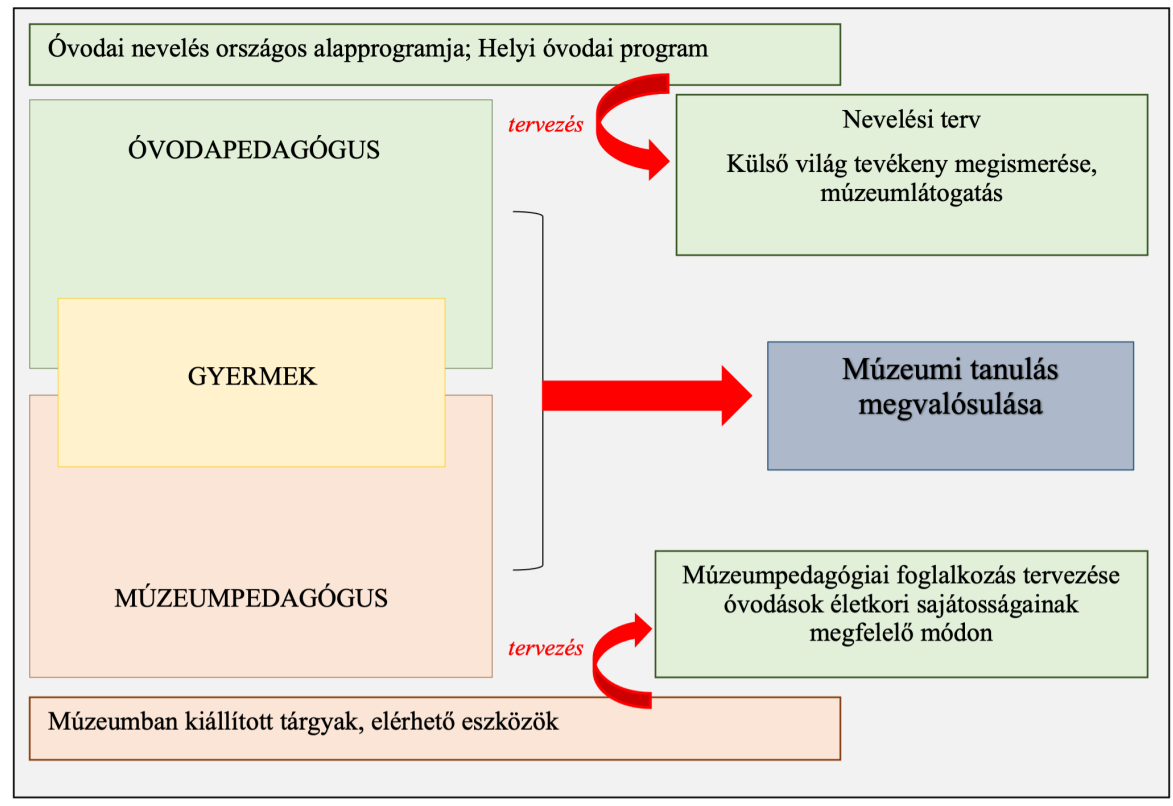

2. ábra

Óvodások múzeumi tanulásában játszó tényezők

Ahhoz, hogy az óvodások múzeumi tanulása teljes mértékben megvalósuljon, nem elég csak bejelentkezni és megvenni a jegyet/bérletet egy-egy múzeumpedagógiai foglalkozásra, kiállításra, ugyanis ennél összetettebb folyamatról van szó, amelyet az általam összeállított 2. ábra foglal össze. Az óvodapedagógus az óvodai nevelést az Alapprogram (2012), illetve a Helyi óvodai program alapján tervezi meg. Óvodáskorban a múzeumi tanulás és élményszerzés, a külső világ tevékeny megismerése során valósulhat meg, amelyet az óvodapedagógus tudatosan, jól megszervezve, komplex módon épít bele óvodai tevékenységrendszerébe. Továbbá előzetesen tájékozódik a múzeum által kínált múzeumpedagógiai foglalkozások lehetőségeiről, hogy az életkori sajátosságoknak megfelelő, tudatos tervezés és szervezés megvalósuljon. Mindezek mellett a múzeumpedagógus munkája sem elhanyagolható, hiszen nagyon sokrétủ és összetett. Amellett, hogy nagyon jól kell ismernie a múzeumban kiállított tárgyakat, azok történetét, eredetét, olyan múzeumpedagógiai foglalkozást kell összeállítania, amely illeszkedik a múzeum környezetébe (a kiállított tárgyakhoz kapcsolódik), és kielégíti az óvodáskorú gyermek kíváncsiságát a fejlettségi szintjének megfelelő módon, amely lehetővé teszi a tanulást és tapasztalatszerzést. Ehhez szükséges a tudatos tervezés, és az életkori sajátosságok pontos ismerete. 
Tehát ahhoz, hogy az óvodás múzeumi tanulása teljes mértékben megvalósuljon, mind a két pedagógus fontos szerepet játszik: az óvodapedagógus nyitottsága és felkészültsége ugyanolyan fontos, mint a múzeumpedagógusé. Ebből következően tehát nem elhanyagolható, hogy a pedagógusok egymás munkáját ismerjék és szakmailag támogassák annak érdekében, hogy az óvodás múzeumi tanulása egy biztonságos környezetben, sok játékkal és élménnyel együtt valósulhasson meg.

\section{A tapasztalatok összegzése}

A témában végzett jelenlegi kutatások alátámasztják, hogy a múzeumnak van helye a köznevelésben, és az oktatási-nevelési folyamatban fontos szerepet játszik a múzeumi tanulás (Beáné Losonci, 2019; Kolosai, 2019; Halászné Szakács, 2017; Takács \&és Csimáné Pozsegovics, 2016a).

Az eredmények azt mutatják, hogy a Magyar Természettudományi Múzeum, illetve a Hetedhét Játékmúzeum olyan múzeumpedagógiai foglalkozásokat kínál, amely lehetővé teszi az óvodáskorú gyermekek múzeumi tanulását. A sokszínű múzeumpedagógiai módszerek, tevékenységiformák, lehetőséget kínálnak a múzeumi aktív tanulás megteremtésére, amelyet érdeklődést felkeltő eszközökkel, kézbe vehető tárgyakkal, jól irányított kérdésekkel valósítanak meg (Koltai, 2011). A múzeumok speciális közegében az óvodai nevelés nem megszokott környezetben, nem megszokott módon és nem csak óvodapedagógusokkal folyik. Ennek ellenére az itt elsajátított, megtapasztalt tartalmak sokkal inkább beépülnek a már megszerzett ismeretek közé, könynyebben előhívhatóak (Takács \& Csimáné Pozsegovics, 2016a).

A kutatásban résztvevők tapasztalatait, véleményeit; illetve a szakirodalmak (Kolosai 2017, 2019; Koltai, 2011; Nagy 2014; Takács \& Csimáné Pozsegovics, 2016b) által feltárt óvodások tanulására vonatkozó elméleti részt összevetve elmondható, hogy a vizsgált múzeumok által biztosított foglalkozások, illeszkednek az óvodai nevelés tevékenységrendszerébe. A múzeumi tapasztalatszerzés a külső világ tevékeny megismerése során valósulhat meg az óvodai nevelésben, amelyet az óvodapedagógus tudatosan megtervez, és előre megszervez, így építi bele mindennapi pedagógiai munkájába.

A kutatásban résztvevők elmondása alapján a múzeumok környezete, berendezése, kiállított tárgyai, a múzeumpedagógiai foglalkozásokon feldolgozott témák mind a felfedezés és tapasztalatszerzés élményét nyújtják az óvodáskorú gyermek számára. A megkérdezett múzeumpedagógusok szerint a játék mellett, az érzékszerveket megmozgató tapasztalás útján történő tanulást a felfedezés élménye, a gyermeki kíváncsiság motiválja. A vizsgálatban résztvevők válaszai alapján a két múzeumban szervezett múzeumpedagógiai foglalkozások során a kiállított tárgyak, jelenségek a megfelelő pedagógiai módszerekkel és tevékenységformákkal kerülnek feldolgozásra, játékos formában. A múzeumpedagógusok elmondása szerint az óvodások múzeumi tanulását a gyermeki kérdésekre, válaszokra épülő ismeretszerzéssel segítik 
elő, illetve biztosítják az irányított megfigyelés, tapasztalatszerzés, felfedezés élményének lehetőségét.

A kutatási eredmények alapján a múzeumok által kínált programokról és a múzeumpedagógusok munkájáról elmondható, hogy mind a két múzeum elkötelezett amellett, hogy az óvodások (az életkori sajátosságoknak megfelelő módon) játszanak, tanuljanak, és új tapasztalatot szerezzenek. A kutatásban vizsgált múzeumi programok a múzeumpedagógusok elmondása alapján megfelelő pedagógiai módszerekkel, tevékenységi formákkal, tudatosan megtervezett múzeumpedagógiai foglalkozásokat biztosítanak. Fontos további kutatásokkal feltárni, vajon a pedagógusok és a pedagógusképzés hogyan tudja hatékonyan kiegészíteni a múzeumpedagógusok munkáját.

\section{Irodalom}

363/2012. (XII. 17.) Kormány rendelet. 1. melléklet a 363/2012. (XII. 17.) Kormány Rendelethez. https://net.jogtar.hu/jogszabaly?docid=a1200363.kor (2020. 03. 23.)

1997. évi CXL. törvény 42. $\mathbb{\$}(1)$. https://net.jogtar.hu/jogszabaly?docid=99700140. tv (2020. 03. 23.)

Arapovics, M. (2017). Közösségi részvételi alapú működés. A múzeumok társadalmiasítása. In Bereczki, I. \& Sári, Zs. (Eds.), Ház és ember. A Szabadtéri Néprajzi Múzeum Évkönyve. 28-29. Tanulmányok Cseri Miklós 60. születésnapja alkalmából (pp. 91-104). Szabadtéri Néprajzi Múzeum.

Atkinson, R. C. \& Hilgard, E. (2005). Pszichológia. Osiris Kiadó.

Ádám, F., Kuti, I. \& Kuti I. (2007). Környezeti nevelés a XXI. század óvodájában. Kecskeméti Főiskola Tanítóképző Fősikolai Kar.

Az ICOM /International Council of Museums/ szakmai etikai kódexe. Fordította: Deme Péter. Szerkesztette: Bezzeg Mária. COM Magyar Nemzeti Bizottsága, 2004. 14. https://icom.museum/wp-content/uploads/2018/07/code-hungary.pdf (2020. 04. 16)

ICOM szakmai etikai kódex. 1986, Alapszabály 2. cikkely 1. pont.

Beáné Losonci, K. (2019). Lehet-e elég korán elkezdeni? Természettudományos irányultságú múzeumpedagógiai foglalkozások óvodások részére. Neveléstudomány: oktatás-kutatás-innováció. 7(2), 42-55. http:// nevelestudomany.elte.hu/downloads/2019/nevelestudomany_2019_2_42-55.pdf (2020. 03. 26.) https://doi.org/10.21549/NTNY.26.2019.2.3

Bihariné dr. Krekó, I. (2006). A világ, amelyben élünk! In Bihariné dr. Krekó, I. (Ed.), Környezeti nevelés az erdőben (pp. 5-9). Öko-Fórum Alapítvány

Bús, I. (2013). A gyermekkultúra vázlata. In Bús, I. (Ed.), Tanulmányok a gyermekkultúráról (pp. 11-24). PTE IGYK és Gyermekkultúra Kutatócsoport.

Chalufour, I. \& Worth, K. (2009). Science in Kindergarten. Reading number 56 from the CD accompanying Developmentally Appropriate Practice in Early Childhood 
Programs Serving Children from Birth through Age 8. Third Edition. National Association for the Education of Young Children.

Elekes, É. (2012). A természettudományos magatartás kialakitásának lehetőségei a Magyar természettudományi Múzeum Kézbe vehető Múzeumának gyermekfoglalkozásian. (Doktori disszertáció). Eötvös Loránd Tudományegyetem Pedagógia és Pszichológia Kar Neveléstudományi Doktori Iskola. http://ppkteszt. elte.hu/file/Elekes_Eva_dissz.pdf (2020.04.01.)

Fraiberg, S. H. (2005). Varázsos évek. Park Könyvkiadó.

Foghtüy, K. \& Harangi, A. (1993, Eds.). Múzeumpedagógia. Útmutató pedagógusok számára. Korona Kiadó.

Foghtűy, K. \& Szepesházyné Kurimay, Á. (2009, Eds.). Múzeumpedagógiai tanulmányok III. Gondolat Kiadó.

Gerő, Zs. (2003). Érzelem, fantázia, gondolkodás óvodáskorban. Flaccus Kiadó.

Golnhofer, E. \& Szabolcs, É. (2005). Gyermekkor: nézőpontok, narratívák. Eötvös József Kiadó.

HalásznéSzakács,É.(2017).Az iskolán kívüli oktatás és nevelés színterei és módszerei. Múzeum-, zoo-, botanikus kerti és erdőpedagógia. In (sz.n.), Tanulmánykötet Mészáros Károly tiszteletére 2017 (pp. 95-119). Soproni Egyetem Kiadó. http:// publicatio.nyme.hu/1340/1/10_HalaszneSzakacsEva_2_Muzeumpedagogia.pdf (2020. 03. 22.)

Hetedhét Játékmúzeum honlapja. https://www.deakgyujtemeny.hu/ (2020.03.21.)

Hetedhét Játékmúzeum. Vonalba zárt történetek. https://szikm.hu/gyujtemenyek/ reber_gyujtemeny-217 (2020.03.22.)

Hollósi, H. (2008). Gyermekkép, gyermekvilág, gyermekfelfogás változásai pedagógiai megközelítésben. Iskolakultúra Online, 2, 92-103. http://misc.bibl.uszeged.hu/45530/1/iol_2008_001_092-103.pdf (2020.04.14.)

Körmöci, K. (2002). A gyermeki játék és a tanulás. ELTE-TOFK, Neveléstudományi Tanszék. http://rmpsz.ro/uploaded/tiny/files/magiszter/2010/tel/05.pdf (2020.04.04.)

Krisztián, Á. (2001). A varázsló trükkjei. In B. Lakatos, M. (Ed.). Játékpszichológia. Olvasókönyv óvodapedagógus hallgatóknak (pp. 205-211). ELTE Eötvös Kiadó.

Kolosai, N. (2016). A gyermekkultúra jelene. In Kolosai, N. \& M. Pintér, T. (Eds.), A gyermekkultúra jelen(tősége) (pp. 9-27). ELTE Tanító- és Óvóképző Kar. http:// www.e-pakk.hu/gykebook.pdf (2020. 04. 14.)

Kolosai, N. (2017). A játék helye, szerepe a minőségi kora gyermekkori nevelésben. In: Pálfi, S. \& Vargáné Nagy, A. (Eds.), Kora gyermekkori nevelés szakmai megújításának útjai, lehetőségei 2 (pp. 44-55). Debreceni Egyetemi Kiadó.

Kolosai, N. (2019). Óvodások a múzeumban. In Boros, T. (Ed.), Múzeumi és könyvtári fejlesztésekmindenkinek (pp.1-17).Szabadtéri Néprajzi Múzeum,Múzeumi Oktatási és Módszertani Központ. https://mokk.skanzen.hu/admin/data/file/20200416/ kolosai_n_ovodasok_a_muzeumban.pdf (2020.04.14.) 
Koltai, Zs. (2010). Helyzetjelentés a hazai múzeumpedagógia eredményeiről és kihívásairól. Iskolakultúra, 20(3). 107-123.

Koltai, Zs. (2011). A múzeumi kultúraközvetités változó világa. A múzeumi kultúraközvetités pedagógiai és andragógiai szempontú vizsgálata. Gondolat Kiadó.

Kovácsné dr. Bakosi, É. (2009). Játék és tanulás az óvodában. https://ofi.oh.gov.hu/ jatek-es-tanulas-az-ovodaban (2020.04.05.)

Lord, B. (2001). The Purpose of Museum Exhibitions. In Lord, B. \& Lord, G. D. (szerk.), The Manual of Museum Exhibitions (pp. 11-25). AltaMira Press.

Lord, B. (2007). What is Museum-Based Learning? In Lord, B. (Ed.). The Manual of Museum Learning (pp. 13-20). AltaMira Press.

Magyar Természettudományi Múzeum. http://www.nhmus.hu/hu/kiallitasok/ allando_kiallitasok (2020.04.16.)

Magyar Természettudományi Múzeum Hivatalos Honlapja. http://www.nhmus.hu/ (2020.03.21.)

Magyar Természettudományi Múzeum Küldetésnyilatkozata. http://www.nhmus. hu/hu/rolunk/kuldetes (2020. 04. 16.)

Millar, S. (1968). Játékpszichológia. Közgazdasági és Jogi Könyvkiadó.

Mérei, F. \& V. Binét, Á. (1970). Gyermeklélektan. Gondolat Kiadó.

Mérei, F. \& V. Binét, Á. (2016). Gyermeklélektan. Libri Kiadó.

Nagy, Á. \& Trencsényi, L. (2013). Szocializációs közegek a változó társadalomban A nevelés esélyei: család, iskola, szabadidö, média. SZT Alapítvány.

Nagy, J. (2014). Környezetóra a múzeumban. Acta Scientiarum Socialium, 41, 3949. https://journal.ke.hu/index.php/asc/article/view/336 (2020.03.24.)

Nagy, V. (2013). Múzeum vagy „csak” játék? A Moskovszky-gyűjtemény muzeológiai értelmezése. Néprajzi Látóhatár, 22(2), 83-103.

Nahalka, I. (2002). Hogyan alakul ki a tudás a gyerekekben?: Konstruktivizmus és pedagógia. Nemzeti Tankönyvkiadó..

OECD (2006). Starting strong II. Early childhood education and care. OECD Publishing. 19-40. https://doi.org/10.1787/9789264035461-en (2020.04.05.)

Postman, N. (1983). The Disappearance of Childhood. W. H. Allen. https://doi. org/10.1016/S0002-7138(09)61523-5

Pukánszky, B. (2004). Fejezetek a gyermekkor és a családi nevelés történetéből. In Németh, A. \& Pukánszky, B. (Eds.), A pedagógia problématörténete (pp. 259330). Gondolat Kiadó.

Ranschburg, J. (2002). A világ megismerése óvodáskorban. Saxum Kiadó.

Réber Konferencia. http://www.deakgyujtemeny.hu/site_hh.cgi?a=cikk\&id=prg_ hh-reberkonf (2020.04.15.)

Szabolcs, É. (2011). Deduktív (analitikus) jellegű kutatások. In Falus, I. (Ed.), Bevezetés a pedagógiai kutatás módszereibe (pp. 84-95). Müszaki Kiadó Kft. 
Szent István Király Múzeum, Múzeumpedagógia. https://szikm.hu/muzeumpedagogia/ (2020.03.22.)

Takács, A. (2013). A művészeti nevelés jó gyakorlatai hazai múzeumokban múzeumpedagógia, a pedagógusok nélkülözhetetlen eszköztára. Gyermeknevelés, 1(2). 48-56. https://doi.org/10.31074/gyntf.2013.2.48.56 (2020.04.16.)

Takács, A. \& Csimáné Pozsegovics, B. (2016a). A múzeumpedagógia integrálása a pedagógusképzésekbe. In Koltai, Zs. (Ed.), IV. Országos Múzeumpedagógiai Konferencia. A IV. Országos Múzeumandragógiai Konferencia válogatott anyaga. Tudásmenedzsment, 17(1), 91-98. https://kpvk.pte.hu/sites/kpvk.pte. hu/files/muzeumandragogiai_konferencia_0.pdf (2020.03.15.)

Takács, A. \& Csimáné Pozsegovics, B. (2016b). Marc Chagall világa - Egy kiállítás múzeumpedagógiai lehetőségei, avagy művészettel nevelés múzeumi környezetben. In Kolosai, N. és M. Pintér, T. (Eds), A gyermekkultúra jelen(töség) e. ELTE Tanító- és Óvóképző Kar, 290-304. http://www.e-pakk.hu/gykebook. pdf (2020.04.14.)

Tancz, T. (2004). A mese dramaturgiája: Kultúrális emlékezet és identitásformálás. In Kolontári, A. \& Papp, L. (Eds.), Tudományos Közlemények (pp. 138-149). VII. PTE IGYFK, Szekszárd.

Tari, A. (2011). Z generáció. Tericum Könyvkiadó.

Torgyik, J. (2018). Tanulás a múzeumpedagógia módszereivel. Eötvös József Könyvkiadó.

Vajda, Zs. (2005). A gyermekkor és a gyermeknevelés történeti távlatokban. In Vajda, Zs. \& Kósa, É. (Eds.), Neveléslélektan (pp. 54-58). Osiris Kiadó. https://regi.tankonyvtar.hu/hu/tartalom/tamop425/2011_0001_520_ neveleslelektan/2011_0001_520_neveleslelektan.pdf (2020.04.14).

Vásárhelyi, T. \& Kárpáti, A. (2011). Múzeumi tanulás. Typotex Kiadó.

Vásárhelyi, T. \& Sinkó, I. (2004). Múzeumaz iskolatáskában. Nemzeti Tankönyvkiadó. 


\section{Pál, F.}

\section{Preschoolers' Museum Activities - Having a good trip. Playing and learning in the world of museums}

A museum, a pedagogical session at a museum, can "open up the world" to the child: they can gain new experiences, ask questions, and get answers, and last but not least, they can learn a culture of behaviour to follow. My study presents the museum learning of preschoolers through the pedagogical programs for preschool children at the Hungarian Museum of Natural History and the Hetedhét Toy Museum. By looking at the possibilities of a wide variety of activities for kindergarteners in museums, the aim of the study is to become acquainted with the pedagogical work in the Hungarian Museum of Natural History and the Hetedhét Toy Museum through empirical research. The focus is on exploring the possibilities of museum pedagogical programs and exhibitions organized by museums, and examining factors necessary to ensure the museum learning of preschool children. In particular, I attempt to highlight the importance of museum pedagogy and museum visits in the development and learning of preschool children. I seek answers to the questions raised by observing museum pedagogical sessions and by the opinions, experiences and perspectives of museum educators, museologists and kindergarten teachers who volunteered to take part in the research.

Keywords: museum, kindergarten, play, learning, Hetedhét Toy Museum, Hungarian Museum of Natural History, science, culture, children's culture

Pál Fanni: https://orcid.org/0000-0003-1688-443X 